Papers and Proceedings of the Royal Society of Tasmania, Volume 108

(ms. received 25.9 .1973 )

\title{
THE LITTORAL ROCK FAUNA OF THREE HIGHLAND LAKES IN TASMANIA
}

by B.V. Leonard, Department of Applied Biology, R.M.I.T., Melbourne, and B.V. Timms, Sciences Department, Avondale College, Cooranbong, N.S.W., : both formerly Department of Zoology, Monash University.

(with one text-figure and three tables)

\section{ABSTRACT}

The littoral rock fauna of Dove Lake, Lakes Sorell and Crescent comprise 14, 26 and 20 species respectively. Within each lake the fauna varies greatly from rock to rock, but in general, rocks resting on stick or leaf litter harbor more individuals than those on rocks or pebbles. Between lakes there is an increase in biomass and a shift from dominance by insects to dominance by non-insects with increasing trophic status. Community structure of the littoral rock fauna in these lakes is compared to that in some European lakes.

\section{INTRODUCTION}

Prior to this study, the littoral rock fauna of only one freshwater lake in Austra1ia had been studied. This lake, Lake Purrumbete in western Victoria, supports few species (Timms 1973) by European standards (Macan and Maudsley 1969; Hunt and Jones 1972) and the littoral rock fauna is dominated by non-insect forms. If Purrumbete is typical, then there is relatively low diversity in the littoral rock biocoenosis in Australian lakes, an aspect which Tillyard (1933) commented upon, but for which no quantitative data was presented. Furthermore, dominance by non-insect forms in Europe indicated lake enrichment (Macan and Maudsley 1969) and, since Purrumbete is strongly mesotrophic (Timms 1973), the same association could well apply in Australian lakes. Data on many other lakes is needed to test the validity of these suggestions.

The littoral rock fauna of Lakes Dove, Sorell and Crescent on the Tasmanian highlands were examined in mid-October 1972, with a view to :-

(a) documenting the types and numbers of species present on the littoral rocks and (b) calculating standing crops of numbers and biomass and relating this data to lake trophic status.

\section{THE LAKES}

Dove Lake is deep $(z=60 \mathrm{~m}$ (Benson 1917)) and lies at an altitude of about $910 \mathrm{~m}$ in the northwest of the Central Highlands. Precambrian schists dominate the rocky shoreline, but there are also some glacially deposited stones composed of Jurassic dolerite and Permian sandstone.

Lake Sorell and Crescent are large and shallow, lying at an altitude of $820 \mathrm{~m}$ near the eastern edge of the central plateau (Cheng 1972). About 75 percent of the shoreline is rocky in each Iake and the rocks are of Jurassic dolerite.

\section{METHODS}

\section{Sampling}

Within each lake, stations with littoral rocks and covering approximately $10 \mathrm{~m}$ of shoreline were arbitrary selected and the substratum type noted. Ten stations were sampled in Dove Lake ( $f$ ig. 1) and five each in Lakes Sorell and Crescent. The stations 
in Lake Sorel1 were in the vicinity of the Interlaken Guest House, and in Lake Crescent in the area just north of the Clyde River outflow.

At each station five rocks ( 10 in Dove) of manageable size $(10-35 \mathrm{~cm}$ long) were carefully removed, a net (mesh size $0.8 \mathrm{~mm}$ ) placed underneath and all the animals on the net and rock removed and preserved in $70 \%$ alcohol for later identification, counting and weighing. The dimensions of the undersurface of each rock were measured; they tended to be rectangular, and were assumed to be so in calculating their area.

\section{Presentation of Data}

In each lake there were large variations in numbers under each rock, and only in Dove Lake did the mean of numbers and biomass at each station exceed the variance. Thus 10 rocks are thought sufficient to characterize a station at Dove Lake, and so data are expressed as numbers and biomass per unit area of rock base per station. However, for Lakes Sorell and Crescent, since the means for each station are thought to be less reliable, data from the stations are combined as grand means for each lake to provide an order of magnitude.

\section{RESULTS}

The relative abundance of each species in each lake is indicated in table 1. In Dove Lake, nine of the 14 species encountered were insects. One species of stonefly and one species of mayfly were especially prevalent, so that insects dominated the fauna, comprising 73 percent of total numbers. In Lakes Sore 11 and Crescent, the number of species and individuals were greater, and insects were not so important. Thus in Lake Sorel1, 50 percent of

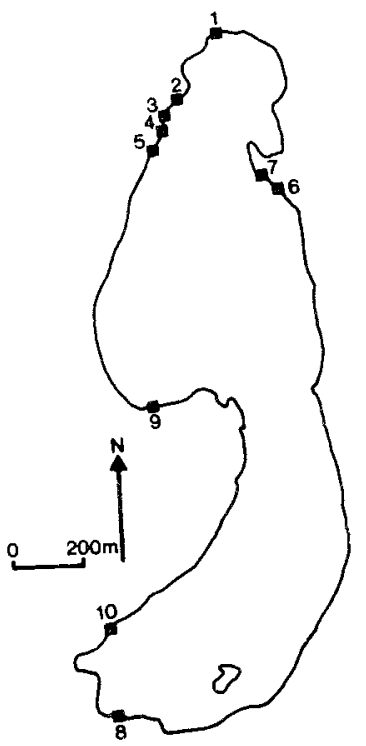
the species were insects (13 out of 26 species), and in Lake Crescent only 40 percent ( 8 out of 20 species).

The numbers and biomass of each species per $\mathrm{m}^{2}$ of rock base per station for Dove Lake are given in table 2. There was considerable variation between stations, and, although the variance between stations was smaller then the mean for all species combined, it approximated the mean when each species was treated separately. Numbers per rock was not correlated with rock size but rather with the nature of the substratum; in general, rocks resting on stick and leaf litter supported most animals and those on large stones, the least.

In Lakes Sorell and Crescent, variation both within and between stations was even greater, and in nearly all cases the variance exceeded the mean. The grand mean for all stations are given in table 3 .

Although Dove Lake had the lowest number of individuals $/ \mathrm{m}^{2}$, biomass $/ \mathrm{m}^{2}$ was relatively high (table 3). In Dove, the dominant forms were large insects whereas in the other lakes the dominants were small in size, though in Crescent there were some large nondominant species.

\section{DISCUSSION}

The most outstanding feature of the littoral fauna of each lake is the variability in numbers, and hence biomass, under each rock and between stations. For instance, in 
TABLE 1

LITTORAL ROCK SPECIES AND THEIR RELATIVE ABUNDANCE IN DOVE LAKE AND LAKES SORELL AND CRESCENT.

\begin{tabular}{|c|c|c|c|c|}
\hline & Species & Dove Lake & Lake Sorell & Lake Crescent \\
\hline \multirow[t]{4}{*}{ Turbellaria: } & Triclad sp A ("striped") & & ++ & +++ \\
\hline & Triclad sp B ("grey") & + & + & + \\
\hline & Triclad sp C ("black") & & ++ & ++ \\
\hline & Triclad sp D ("big white") & + & ++ & + \\
\hline oligochaeta: & Unidentified sp. or spp. & + & ++ & + \\
\hline Hirundinea : & Unidentified sp. & & & + \\
\hline \multirow[t]{7}{*}{ Crustacea : } & Austrochiltonia australia & & ++ & \\
\hline & A. subtenuis & & & +++ \\
\hline & "Gommarus", cf australis & + & & \\
\hline & Neoniphargus cf exiguus & & & + \\
\hline & "PseudaseZZus" & & + & ++ \\
\hline & ?Colubotelson thomsoni & & + & ++ \\
\hline & Paratya "tasmaniensis" & & ++ & \\
\hline \multirow[t]{19}{*}{ Insecta } & Atalonella delicatula & & ++ & \\
\hline & Atalonelza sp B & & & + \\
\hline & Ataloneliza sp C & ++ & & \\
\hline & Eusthenia sp & ++ & + & ++ \\
\hline & Leptoperta sp & + & + & + \\
\hline & Cardioperia sp & & ++ & \\
\hline & Helicopsyche sp & & ++ & \\
\hline & Caddis sp B. (F. Leptoceridae) & + & + & + \\
\hline & Caddis sp C (F. Psychomyiidae) & + & & \\
\hline & Sclerocyphon aquaticus & + & + & \\
\hline & simsonia sp & & + & \\
\hline & Platynectes decempunctatus & & & + \\
\hline & Dytiscid larvae & & + & \\
\hline & Tabanid larvae & & + & \\
\hline & Limoniinid larvae & + & + & \\
\hline & Orthoclad larvae sp A & + & & \\
\hline & Orthoclad larvae sp B & + & & \\
\hline & Orthoclad larvae sp C & & + & + \\
\hline & Ceratopogonid larvae & & + & \\
\hline \multirow[t]{5}{*}{ Mollusca } & Potomopyrgus niger & & ++ & 7 \\
\hline & Potomopyrgus sp B & & & ++ \\
\hline & Bulinus hainesii & & + & + \\
\hline & Gyraulus scottianus & & + & \\
\hline & Pisidium sp. near casertanum & + & + & + \\
\hline \multicolumn{2}{|l|}{ TOTAL } & 14 & 26 & 20 \\
\hline
\end{tabular}

Code $\quad+$ infrequent; ++ present; +++ abundant; ++++ very abundant. 
TABLE 2

SUMMARY OF NUNBERS AND BIOMASS OF LITTORAL ROCK FAUNA IN DOVE LAKE

\begin{tabular}{|c|c|c|c|c|}
\hline $\begin{array}{l}\text { Station } \\
\text { number }\end{array}$ & substratum & $\begin{array}{c}\text { area of rocks } \\
\mathrm{m}^{2}\end{array}$ & number $/ \mathrm{m}^{2}$ & wet biomass $/ \mathrm{m}^{2}$ \\
\hline 1 & large rocks & 0.805 & 7.45 & 0.094 \\
\hline 2 & large rocks & 0.567 & 22.93 & 0.140 \\
\hline 3 & $\begin{array}{c}\text { pebbles on stick and leaf } \\
\text { litter }\end{array}$ & 0.561 & 41.00 & 1.423 \\
\hline 4 & large rocks & 0.527 & 37.95 & 1.200 \\
\hline 5 & sma11 rocks & 0.506 & 23.72 & 0.443 \\
\hline 6 & pebbles & 0.379 & 23.75 & 0.352 \\
\hline 7 & large rocks & 0.488 & 24.59 & 0.185 \\
\hline 8 & rocks on stick and leaf litter & 0.563 & 47.96 & 1.667 \\
\hline 9 & sma 11 rocks & 0.278 & 50.36 & 0.360 \\
\hline 10 & rocks on stick and leaf litter & 0.417 & 69.54 & 2.559 \\
\hline Mean & & & 34.93 & 0.843 \\
\hline Variance & & & 17.97 & 0.831 \\
\hline
\end{tabular}

TABLE 3

RELATIONSHIP BETWEEN TROPHIC STATUS, STANDING CROP AND COMMUNITY STRUCTURE OF LITTORAL ROCK FAUNA.

\begin{tabular}{|c|c|c|c|c|c|c|}
\hline & \multicolumn{2}{|l|}{ Trophic Status } & \multicolumn{2}{|c|}{ Standing Crop $/ \mathrm{m}^{2}$} & \multicolumn{2}{|c|}{ Community Structure } \\
\hline & $\begin{array}{l}\text { designation } \\
\text { designation }\end{array}$ & $\begin{array}{l}\text { primary } \\
\text { production } \\
\left(\mathrm{mgC} / \mathrm{m}^{2} / \text { day }\right)\end{array}$ & number & $\begin{array}{c}\text { wet } \\
\text { biomass }\end{array}$ & A & $\mathrm{B}$ \\
\hline Dove & oligotrophict & - & 35 & 0.8 & 64 & 73 \\
\hline Sore11 & oligotrophic & $44.0+$ & 770 & 0.5 & 50 & 43 \\
\hline Crescent & $\begin{array}{c}\text { weakly } \\
\text { mesotrophic }\end{array}$ & $115.4+$ & 600 & 1.5 & 40 & 7 \\
\hline Purrumbete & $\begin{array}{c}\text { strongly } \\
\text { mesotrophic }\end{array}$ & $293.0^{\phi}$ & $10,600^{\phi}$ & $8.4^{\varnothing}$ & 43 & 5 \\
\hline
\end{tabular}

A - percentage of species that are insects

$B$ - percentage of individuais that are insects

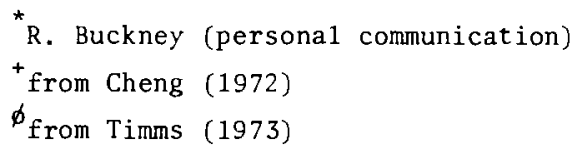


Lake Sorell, one rock hid three individuals (one species), while an adjacent one had 23 individuals (11 species) under it.

This variability may be due to:-

(a) rock size - data from Dove Lake suggest that rock size within the range studied, is unimportant.

(b) the surface configuration of the rock or the degree of rugosity - many rocks contain pits and fissures that provide refuges for fauna. The importance of this is difficult to measure in the field.

(c) the percentage of the surface of rock in contact with the substratum.

(d) the underlying substratum type - there is definite evidence from all lakes that this is an important variable. Rocks on stick and leaf litter or on weed substrata harbour more animals than those on pebbles or rocks. There was also a tendency for fewer animals with increasing substratum particle size (table 2).

(e) the position of the station in the lake - In Dove Lake the two stations at the upper end of the lake had the highest biomass. This agrees with data on benthos for this lake (Timms, in prep.). Also, Macan and Maudsley (1969) showed variation in faunal abundance with position in a lake.

(f) depth below water surface.

(g) wave action in relation to prevailing winds.

Because of this variability, we suggest that many rocks per station and numerous stations per lake are needed to characterize the littoral rock fauna of a lake. On these criteria, the Dove Lake data are reasonably reliable, but those for Sorell and Crescent are not.

There have been numerous studies on the littoral fauna of European lakes but on $1 y$ two, those of Macan and Maudsley $(1968,1969)$, examine rock fauna alone. Since there are fewer species in the benthic faunas of Australian lakes than in those of the Northern Hemisphere (Timms 1973), the same may be true for the littoral rock fauna. Thus Lake Purrumbete, which was studied intensively, yielded 10 species of littoral rock insects (Timms 1973) whereas Lake Windemere in England supports 48 species of insects on littoral rocks (Macan and Maudsley, 1968). Also, although sampling was not intensive, the three Tasmanian lakes yielded a maximum of 15 littoral rock insect species in any one lake.

Macan and Maudsley (1969) show further that insects are generally more prevalent in numbers and species in unproductive waters, and are replaced by non-insects in enriched regions. To illustrate this we estimate from their data that on ly 0.5 percent of individuals (one out of 10 species) were insects at a eutrophic station in Lake Windermere, while at an ologotrophic station in the same lake, 70 percent of the fauna (eight out of 11 species) were insects. Much the same phenomenon is seen in the present Tasmanian lakes and in Lake Purrumbete. There is a moderate decrease in the proportion of insect species to non-insect species with increasing trophic status of a lake and a large decrease in the proportion when numbers of individuals are considered ( $t a b l e ~ 3$ ).

The relationship between the proportion of insect species and lake trophic status may not be as simple as portrayed. For instance, Dove Lake has been isolated since the retreat of the glacier from the area late in the Pleistocene and may not have received some less mobile forms. Also, Lake Purrumbete is about $2 \frac{1}{2}$ times more productive than Crescent, yet the insect/non-insect ratios are similar in each. Further, the Kosciusko lakes, which are oligotrphic, contain a relatively rich crustacean fauna as well as many insects (knott, personal communication). Thus more data is still needed. However, it will be remarkable if the relationship is valid, for the faunas of the Northern and Southern Hemispheres have probably had dissimilar evolutionary histories. 
Macan and Maudsley's (1969) figures also show that non-insects are especially numerous in highly productive waters. Likewise, our data reveal an increase in standing crop with increasing trophic status (table 3 ). The contrast between oligotrophic Dove Lake and strongly mesotrophic Lake Purrumbete is marked. This is despite the figure for Dove Lake probably being a seasonal peak, due to the dominant insects being largely in pre-adult instars.

\section{ACXNOWLEDGEMENTS}

We wish to thank Dr J. Martin of Melbourne University for field assistance, Miss $\mathrm{J}$. Smith for biomass determinations and the following taxonomists for their identifications:- Mr B. Knott, University of Tasmania, hobart (Phreatoicoidea); Mr A. Nebois, National Museum, Melbourne (Trichoptera, Coleoptera except Psephenidae); Dr B. Smith, National Museum, Melbourne (Mollusca); Dr W.D. Williams, Monash University, Clayton, (Crustacea except Phreatoicoidea): and Dr P. Zwick, Max Planck Institute, Schlitz, West Germany (Ephemeroptera, Plecoptera, Psephenidae).

We appreciate the comments by Dr P.S. Lake, University of Tasmania, on an early draft of the manuscript.

\section{REFERENCES}

Benson, W.N., 1917: Notes on the geology of the Cradle Mountain District. Pap. Proc. R. Soc. Tasm., (1916), 29-43.

Cheng, D.M.H., 1972: Lake Sore 2 and Lake Crescent, a phycological enigma. Ph. D. Thesis (unpub1.) University of Tasmania.

Hunt, P.C. and Jones, J.W., 1972: The littoral fauna of Llynn Celyn, north Wales. J. Fish. Biol., 4, 321-31.

Macan, T.T., and Maudsley, R., 1968: The insects of the stony substratum of Windermere. Trans. Soc. Er. Ent., 18, $1-18$.

., 1969: Fauna of the stony substratum in lakes in the English Lake District. Verh. int. Ver. Limnol., 17, $173-80$.

Tillyard, R.J. 1933: Report on the problem of trout food in the lakes and rivers of Tasmania. Appendix A of "Salmon and Freshwater Fisheries Commission: Report for year ending zoth June, 1933", Parliament of Tasmania.

Timms, B.V., 1973: A comparative study of the limnology of three maar lakes in western Victoria. Ph. D. Thesis, (unpub1.), Monash University. 